\title{
Analisis Pendapatan Agroindustri Aneka Keripik Putri Tunggal di Kecamatan Bangko Kabupaten Merangin
}

\author{
Sabaruddin \\ Program Studi Agribisnis, Fakultas Pertanian Universitas Muara Bungo, Jambi
}

\begin{abstract}
ABSTRAK
Penelitian ini dilakukan untuk mengetahui nilai pendapatan yang diperoleh oleh pengusaha Agroindustri Aneka Keripik Putri Tunggal di Kecamatan Bangko Kabupaten Merangin dalam menjalankan usaha Agroindustrinya. Pemilihan lokasi dilakukan secara sengaja (purposive) karena usaha Agroindustri Aneka Keripik ini merupakan salah satu usaha Agroindustri di Kecamatan Bangko Kabupaten Merangin yang masih aktif berproduksi secara kontinyu dan aneka produknya mempunyai prospek yang cukup baik untuk dikembangkan kerena potensi pasar yang sangat mendukung. Dari hasil penelitian diketahui pendapatan yang diterima pengusaha Agroindustri Aneka Keripik Putri Tunggal Rp. 485.525, nilai R/C ratio 1,12 dan BEP pada saat perusahaan memproduksi 730 bungkus dengan harga jual Rp. 2.925. per satu kali proses pruksi. Masih belum optimalnya pendapatan yang diperoleh dari usaha ditempat penelitian disebabkan oleh tingginya biaya produksi dan masih rendahnya teknologi yang dipakai dalam proses prouksi dan pada waktuwaktu tertentu ketersedian bahan baku produksi seperti pisang dipasar setempat kurang mencukupi kebutuhan, sehingga harus didatangkan dari daerah luar hal ini akan menambah biaya produksi
\end{abstract}

Kata Kunci : Agroindustri, keripik, pendapatan

\section{Pendahuluan}

Pengembangan agroindustri dengan bahan baku yang tersedia dalam jumlah dan waktu yang sesuai, merupakan syarat kecukupan untuk berproduksi secara berkelanjutan. Optimalisasi nilai tambah dicapai pada pola industri yang berintegrasi langsung dengan usahatani keluarga dan perusahaan pertanian. Salah satu agenda pembangunan Indonesia dalam rangka meningkatkan kesejahteraan rakyat adalah melalui pemberdayaan usaha mikro kecil menengah (UMKM). Pengembangan UMKM diharapkan dapat menyerap kesempatan kerja sekaligus meningkatkan pendapatan pelakunya (Pemerintah Republik Indonesia, 2005). Usaha agroindustri aneka kripik termasuk kedalam agroindustri makanan

Alamat Korespondensi:

Kampus I, Prodi Agribisnis, Fakultas Pertanian Universitas

Muara Bungo. Jl. Lintas Sumatera. Sungai Binjai Muara

Bungo. Jambi dengan bahan baku utama hasil pertanian merupakan usaha tradisional yang banyak dilakukan masyarakat dan telah berkembang sejak lama di Kabupaten Merangin. Usaha ini dilakukan turun temurun meskipun dari skala usaha sebagian kurang berkembang dengan baik. Pada tahun 2012 terdapat 25 unit industri kecil aneka makanan ringan dengan produksi aneka kripik yang tersebar di seluruh Kabupaten Merangin dengan sentra produksi di daerah Kecamatan Bangko (Dinas Koperasi Perindustrian dan Perdagangan Kabupaten Merangin, 2012). Industri kecil yang ada di Kabupaten Merangin sebagian besar merupakan usaha informal yaitu belum memiliki ijin usaha dari pemerintah, hanya sebagian kecil yaitu 4 unit usaha yang merupakan usaha formal atau telah memiliki ijin usaha dari pemerintah, hal ini dikarenakan banyaknya persyaratan yang harus dilengkapi seperti Ijin Mendirikan Bangunan (IMB) dimana sebagian besar dari 
mereka tidak memilikinya. Sampai saat penelitian dilakukan tidak ada masalah yang dihadapi para pengrajin aneka makanan kripik mereka dapat tetap berproduksi meskipun tidak meiliki ijin usaha, tetapi Dinas Koperasi Perindustrian dan Perdagangan Kabupaten Merangin tetap menggalakkan pentingnya memiliki ijin usaha sehingga mereka dapat berproduksi dengan tenang karena telah mendapat ijin usaha dari pemerintah. Usaha Aneka kripik Putri Tunggal merupakan pengembangan agroindustri aneka kripik yang termasuk bahan makanan kudapan (snack) di Kabupaten Merangin masih dihadapkan pada kendala seperti keterbatasan bahan baku terutama pisang pada waktu-waktu tertentu sulit di pasaran sehingga sering didatangkan dari kabupaten lain seperti Kabupaten Kerinci terkadang dari Provinsi Bengkulu dan kurangnya tenaga kerja. Hal itu menyebabkan kuantitas produksi dan kontinyuitas produksi aneka kripik masih rendah sehingga keuntungan yang diperoleh belum optimal. Dengan melihat kenyataan yang ada dimana agroindustri aneka kripik pada usaha anake kripik Putri Tunggal di Kabupaten Merangin masih belum optimal maka perlu diadakan penelitian untuk mngkaji sejauh mana nilai pendapatan industri aneka kripik Putri Tunggal di Kabupaten Merangin.

Salah satu sifat produk pertanian adalah mudah rusak (perishable) sedangkan konsumsi berlangsung dalam jangka waktu yang lama. Untuk itu upaya memenuhi konsumsi antara lain melalui pengolahan hasil pertanian. Ditinjau dari segi ekonomi, pengolahan hasil pertanian dapat meningkatkan pendapatan yaitu, meningkatkan daya awet komoditas pertanian dan memberikan keuntungan bagi pengolah. Pengolahan aneka kripik merupakan salah satu tindakan yang tepat dalam meningkatkan daya tahan serta nilai tambah pisang dan ubi kayu atau singkong, sehingga menjadi produk yang sesuai dengan kebutuhan konsumen dan memiliki pendapatan sehingga diharapkan dapat merangsang kegiatan agroindustri, terutama pengolahan aneka kripik.

Agroindustri

dapat

mentransformasikan output pertanian menjadi input agroindustri. Output pertanian yang tidak dapat diserap pasar masih dapat digunakan sebagai bahan baku industri, yang berarti melimpahnya produksi diwaktu-waktu tertentu tidak akan beresiko. Pengolahan bahan kripik menjadi makanan cemilan merupakan bentuk hubungan kerjasama yang saling menguntungkan antara petani, pengelola, pengecer dan konsumennya. Kenaikan pendapatan rumah tangga pengelola sendiri disebabkan adanya nilai tambah dari produk yang dihasilkan dan balas jasa tenaga kerja yang terlibat dalam agroindustri. Kesediaan konsumen membayar output agroindustri yang lebih tinggi dari pada bahan baku merupakan intensif menarik bagi pengelola industri tersebut. Apabila harga output agroindustri yang lebih tinggi ini dapat ditransmisikan kepada produsen, maka dapat memperbesar harga yang diterima pengelola yang sekaligus merupakan intensif bagi pengusaha untuk meningkatkan produksinya.

\section{Metode}

Penelitian ini merupakan jenis survey. Penelitian survey dapat memastikan berapa besar pengaruh yang disebabkan oleh satu variabel dalam hubungannya dengan variasi yang disebabkan oleh variabel lain (Rakhmat, 2005). Pendekatan penelitian adalah kuantitatif, data yang digunakan dalam penelitian adalah data kuantitatif yang didukung oleh data kualitatif. Data kuantitatif dilakukan dengan metode survey, yaitu melalui kuesioner sebagai instrumen utama penelitian. Sedangkan data kualitatif sebagai pendukung penelitian melalui wawancara untuk mendapatkan keterangan tambahan dari responden.

Populasi dalam penelitian ini adalah usaha agroindustri aneka kripik yang ada di Kabupaten Merangin. Metode pengambilan sampel dilakukan dengan menggunakan sensus. Setelah melakukan sensus maka peneliti mendapatkan sampel dalam penelitian ini adalah hanya 1 unit usaha aneka kripik yang masih aktif melakukan produksi secara kontinyu yaitu usaha kripik Putri Tunggal Talang Kawo. Penentuan responden tersebut berdasarkan sensus bahwa ada dari ke 6 unit usaha kripik yang ada di Kecamatan Bangko Kabupaten Merangin 
Data yang diperoleh diolah dan dianalisis dengan pendekatan kuantitatif. Data kuantitatif diolah dan disajikan dalam bentuk tabel. Hal yang pertama kali dilakukan dalam mengolah data adalah menyusun daftar variabel-variabel yang akan ditabulasikan ke dalam tabel yang telah disiapkan

Analisis Pendapatan

Untuk menghitung total biaya produksi dapat dihitung dengan menggunanakan rumus:

$$
T C=T V C+T F C
$$

Keterangan : $\mathrm{TC}=$ Total Biaya (dalam Rupiah)

TVC $=$ Total Biaya Variabel (dalam Rupiah)

TFC $=$ Total Biaya Tetap (dalam Rupiah)

(Sumber: Noor, 2007)

Pendapatan dihitung melalui pengurangan antara penerimaan dengan satu kali biaya proses produksi, dihitung dengan rumus :

a. Penerimaan

$$
\mathbf{T R}=\mathbf{P} . \mathbf{Q}
$$

Keterangan : TR $=$ Penerimaan Total (dalam Rupiah)

$P=$ Harga jual per unit (dalam Rupiah)

$\mathrm{Q}=$ Jumlah produksi (unit) (Sumber : Noor, 2007)

b. Keuntungan

$$
\begin{aligned}
\boldsymbol{\pi}= & \mathbf{T R}-\mathbf{T C} \\
\text { Keterangan }: & \boldsymbol{\pi}=\text { Total keuntungan (dalam Rupiah) } \\
\text { TR } & =\text { Total penerimaan (dalam Rupiah) } \\
\mathrm{TC} & =\text { Total biaya (dalam Rupiah) }
\end{aligned}
$$

(Sumber: Noor, 2007)

\section{Revenue Cost Ratio (R/C) dan Analisis menunjukkan nilai penerimaan yang Titik Impas (BEP) \\ $\mathrm{R} / \mathrm{C}$ ratio merupakan perbandingan diperoleh dari setiap rupiah yang dikeluarkan. Adapun $\mathrm{R} / \mathrm{C}$ ratio dapat dirumuskan sebagai antara penerimaan total dan biaya total, yang berikut.}

$$
R / C=\frac{T R}{T C}
$$

Keterangan: $\mathrm{TR}=$ Total penerimaan

$\mathrm{TC}=$ Total biaya

Kriteria penilaian $\mathrm{R} / \mathrm{C}$ ratio:

$\mathrm{R} / \mathrm{C}<1=$ usaha agroindustri mengalami kerugian

$\mathrm{R} / \mathrm{C}>1=$ usaha agroindustri memperoleh keuntungan

$\mathrm{R} / \mathrm{C}=1=$ usaha agroindustri mencapai titik impas

(Sumber: Noor, 2007) 
Perhitungan BEP atas dasar unit rupiah dapat dilakukan dengan menggunakan rumus:

a. Pendekatan volume produksi

$$
\text { BEP }=\frac{\text { TFC }}{\text { Harga Jual Per Unit }}
$$

b. Pendekatan harga produksi

$$
\mathrm{BEP}=\frac{\text { TFC }}{\text { Produksi total }} \quad \text { (Tim Lentera, 2002) }
$$

HASIL

\section{Analisis Usaha Aneka Kripik Putri \\ Tunggal}

Analisis usaha digunakan untuk mengetahui besarnya pendapatan yang terdapat bahan baku anke kripik yang diolah menjadi kripik. Besarnya analisis untuk satu kali proses produksi pada aneka kripik Putri Tunggal adanya biayabiaya yang harus dikeuarkan yaitu biaya produksi. Biaya produksi pada penelitian ini adalah biaya yang harus dikeluarkan selama proses produksi berlangsung. Biaya produksi meliputi biaya tetap dan biaya variabel, biaya tetap merupakan biaya penyusutan alat dan biaya tenaga kerja, sedangkan biaya variabel meliputi biaya bahan baku dan biaya bahan penolong.

\section{Biaya Tetap}

Dalam menjalankan usaha aneka kripik Putri Tunggal mempunyai biaya rutin yang harus dikeluarkan setiap kali proses produksi ada. Biaya tetap merupakan jenis biaya yang selama satu kali proses produksi adalah tetap jumlahnya dan tidak mengalami perubahan. Dalam proses produksi pembuatan aneka kripik yang merupakan biaya tetap adalah biaya penyusutan alat dan biaya tenaga kerja.

\section{Penyusutan}

Teknologi yang digunakan dalam proses pembuatan aneka kripik masih tergolong teknologi sederhana, mulai dari proses pengupasan sampai penggorengan. Hal ini berkaitan dengan keterbatasan modal dan tingkat pendidikan pekerjanya. Disamping itu dengan menggunakan teknologi yang masih relatif sederhana sehingga dapat membantu masyarakat sekitar dalam bentuk penyerapan tenaga kerja. Dalam suatu usaha, biaya yang dikeluarkan untuk peralatan dihitung melalui penyusutan yang terjadi pada peralatan tersebut. Besarnya biaya penyusutan untuk peralatan dapat dilihat pada Tabel 5 .

Tabel 5. Biaya Penyusutan Peralatan per Proses Produksi Aneka Kripik

\begin{tabular}{|l|c|r|r|r|}
\hline \multicolumn{1}{|c|}{ Jenis Alat } & $\begin{array}{c}\text { Jumlah } \\
\text { (Unit) }\end{array}$ & $\begin{array}{c}\text { Harga Beli } \\
\text { Alat } \\
\text { (per unit) }\end{array}$ & $\begin{array}{c}\text { Umur } \\
\text { Ekonomis } \\
\text { (Thn) }\end{array}$ & $\begin{array}{c}\text { Nilai } \\
\text { Penyusutan } \\
\text { (Rp) }\end{array}$ \\
\hline Penggorengan & 4 & 280.000 & 10 & 306,84 \\
\hline Nampan & 20 & 15.000 & 2 & 410,95 \\
\hline Pemompa minyak & 1 & 325.000 & 4 & 222,6 \\
\hline Perajang & 9 & 45.000 & 1 & $1.109,58$ \\
\hline Timbangan & 2 & 150.000 & 5 & 164,38 \\
\hline Kipas Angin & 2 & 200.000 & 10 & 111,11 \\
\hline Total biaya penyusutan alat & $\mathbf{2 . 3 2 5 , 4 6}$ \\
\hline
\end{tabular}


Dari Tabel 5 diketahui biaya penyusutan pada Perusahaan "Aneka Kripik Putri Tunggal, penyusutan peralatan yang dinilai paling besar adalah penyusutan alat perajang yaitu sebesar Rp 1.109,58 dan penyusutan peralatan yang nilainya paling kecil adalah penyusutan kipas angin yaitu sebesar Rp 111,11.

\section{Biaya Tenaga Kerja}

Tenaga kerja adalah tenaga yang terlibat langsung dalam proses produksi pengolahan aneka kripik, tenaga kerja dimasukkan pada biaya tetap dikarenakan jumlah tenaga kerja setiap proses produksi tidak berkurang atau tetap. Pada Perusahaan Putri Tunggal Pendapatan Tenaga Kerja Langsung untuk satu kali proses produksi adalah sebesar $\mathrm{Rp}$ 75.000 sebanyak 4 orang.

\section{Total Biaya Tetap}

Besarnya biaya tetap merupakan penjumlahan dari biaya penyusutan dan biaya tenaga kerja adapun total biaya tetap yang dikeluarkan oleh aneka kripik Putri Tunggal dalam satu kali proses produksi sebagai berikut

Tabel 6. Biaya Tetap Aneka Kripik Pisang per Proses Produksi

\begin{tabular}{|l|r|}
\hline Jenis Biaya & \multicolumn{1}{|c|}{ Nilai (Rp) } \\
\hline Penyusutan alat & $2.325,46$ \\
\hline Biaya Tenaga Kerja & 300.000 \\
\hline Total Biaya & $302.325,46$ \\
\hline
\end{tabular}

Dari tabel 6 diketahui bahwa besarnya biaya tetap adalah Rp. 30.325 biaya terbesar adalah biaya untuk tenaga kerja sebesar Rp. 300.000

\section{Biaya Variabel}

Biaya variabel adalah biaya yang harus dikeluarkan sebagai biaya pendukung proses produksi pembuatan aneka kripik. Biaya variabel merupakan biaya-biaya yang dipergunakan untuk satu kali produksi, adapun biaya variabel tersebut adalah biaya pembelian bahan baku dan dan sumbangan input lain

\section{Bahan Baku}

Bahan baku yang digunakan dalam proses produksi kripik pisang yaitu pisang dan kripikubi yaitu ubi kayu atau singkong. Perusahaan Putri Tunggal memperoleh bahan baku dengan membeli dari petani dipasar. Produsen membutuhkan bahan baku pisang untuk keripik pisang sebanyak $80 \mathrm{~kg}$ per hari, tiap $\mathrm{kg}$ dibeli dari petani seharga Rp 4.000 biaya bahan baku per proses produksi kripik pisang adalah Rp 320.000, bahan baku untuk sale pisang sebanyak $60 \mathrm{~kg}$ per hari, tiap $\mathrm{kg}$ dibeli dari petani seharga Rp 3.500 biaya bahan baku per proses produksi kripik pisang adalah Rp 210.000 sedangkan bahan baku singkong untuk kripik ubi tiap kg seharga Rp. 2.200 sehingga biaya produksi untuk kripik ubi 100 kg sebesar Rp. 220.000.

\section{Biaya Pendukung Produksi}

Biaya pendukung produksi merupakan bahan penolong adalah minyak goreng, bumbu, sumbangan input lain tersebut diperoleh dengan membeli langsung pada toko atau agen. Lebih jelasnya sumbangan input lain aneka kripik pisang pada Perusahaan Putri Tunggal dapat dilihat pada tabel 7 . 
Tabel 7. Biaya Sumbangan Biaya Aneka Kripik

\begin{tabular}{|c|c|c|c|}
\hline \multicolumn{4}{|l|}{ 1. Kripik Pisang } \\
\hline Bahan Penolong & Volume & Harga $(R p$ & Total (Rp) \\
\hline Minyak goreng & $15 \mathrm{Kg}$ & 10.000 & 150.000 \\
\hline Gula Pasir & $0,75 \quad \mathrm{Kg}$ & 10.000 & 7.500 \\
\hline \begin{tabular}{|l} 
Penyedap \\
\end{tabular} & 1 Unit & 7.000 & 7.000 \\
\hline Bahan Bakar (Kayu) & 2 Ikat & 15.000 & 30.000 \\
\hline Kemasan (plastik +merk) & 300 Lbr & 300 & 90.000 \\
\hline \begin{tabular}{|l|} 
Jumlah \\
\end{tabular} & & & 284.500 \\
\hline \multicolumn{4}{|l|}{ 2. Sale Pisang } \\
\hline \begin{tabular}{|l|} 
Bahan Penolong \\
\end{tabular} & Volume & Harga (Rp) & Total (Rp) \\
\hline Minyak goreng & $10 \mathrm{Kg}$ & 10.000 & 100.000 \\
\hline \begin{tabular}{|l|} 
Gula Pasir \\
\end{tabular} & $0,40 \mathrm{Kg}$ & 10.000 & 4.000 \\
\hline Tepung & $5 \mathrm{Kg}$ & 9.000 & 45.000 \\
\hline Bahan Bakar (Kayu) & 2 lkat & 15.000 & 30.000 \\
\hline \begin{tabular}{|l|} 
Kemasan (plastik +merk) \\
\end{tabular} & 150 Lbr & 300 & 45.000 \\
\hline Jumlah & & & 224.000 \\
\hline \multicolumn{4}{|l|}{ 3. Kripik ubi } \\
\hline \begin{tabular}{|l} 
Bahan Penolong \\
\end{tabular} & Volume & Harga (Rp) & Total (Rp) \\
\hline Minyak goreng & $15 \quad \mathrm{Kg}$ & 10.000 & 150.000 \\
\hline Penyedap & 1 Paket & 5.000 & 5.000 \\
\hline Bahan Bakar (Kayu) & 2 Ikat & 15.000 & 30.000 \\
\hline Kemasan (plastik +merk) & 280 Lbr & 300 & 84.000 \\
\hline Jumlah & & & 269.000 \\
\hline
\end{tabular}

Perusahaan Aneka kripik Putri Tunggal menghabiskan biaya pendukung produksi sebesar Rp 284.500 per proses produksi kripik pisang, sedangkan menghabiskan biaya sebesar Rp 224.000 per proses produksi untuk biaya pendukung produksi pada perhitungan biaya produksi pengolahan pisang menjadi sale pisang dan untuk kripik ubi perusahaan Putri Tunggal menghabiskan biaya Rp. 269.000 untuk sumbangan input pada perhitungan biaya pengolahan singkong menajdi keripik ubi.

\section{Total Biaya Variabel}

Total biaya variabel merupakan biaya yang jumlah totalnya akan mengalami perubahan sebanding dengan perubahan volume kegiatan. Dalam proses produksi kripik pisang, sale pisang dan kripik ubi yang termasuk biaya variabel adalah biaya bahan baku, biaya sumbangan input lain, bumbu. Adapun biaya variabel dalam satu kali proses produksi dapat dilihat pada Tabel 8 .

Tabel 8. Total Biaya Variabel Aneka Kripik per Proses Produksi

\begin{tabular}{|l|r|r|r|}
\hline \multirow{2}{*}{\multicolumn{1}{|c|}{ Jenis Biaya }} & \multicolumn{3}{|c|}{ Nilai (Rp) } \\
\cline { 2 - 4 } & \multicolumn{1}{|c|}{ Kripik Pisang } & \multicolumn{1}{c|}{ Sale Pisang } & \multicolumn{1}{c|}{ Kripik Ubi } \\
\hline & 320.000 & 210.000 & 220.000 \\
\hline Bahan Baku & 284.500 & 224.000 & 269.000 \\
\hline Sumbangan Input lain & $\mathbf{6 0 4 . 5 0 0}$ & $\mathbf{4 3 4 . 0 0 0}$ & $\mathbf{4 8 9 . 0 0 0}$ \\
\hline Total Biaya &
\end{tabular}


Data tabel 8 diketahui bahwa total biaya variabel setiap kali proses produksi pada aneka kripik Putri Tunggal untuk pembuatan kripik pisang Rp. 604.500, sedangkan untuk pembuatan sale pisang sebesar Rp. 434.000 dan untuk pembuatan kripik ubi biaya variabel yang harus dikeluarkan sebesar Rp. 434.000 .

\section{Biaya Total}

Biaya total diperoleh dari penjumlahan antara biaya tetap dengan biaya variabel. Besarnya biaya total dalam proses produksi kripik pada aneka kripik Putri Tunggal dapat dilihat pada Tabel

9.

Tabel 9. Total Biaya Aneka Kripik per Proses Produksi

\begin{tabular}{|l|c|c|c|}
\hline \multirow{2}{*}{ Jenis Biaya } & \multicolumn{3}{|c|}{ Nilai (Rp) } \\
\cline { 2 - 4 } & Kripik Pisang & Sale Pisang & Kripik Ubi \\
\hline Biaya Tetap & 302.325 & 302.325 & 302.325 \\
\hline Biaya Tidak Tetap & 604.500 & 434.000 & 489.000 \\
Total Biaya & $\mathbf{9 0 6 . 8 2 5}$ & $\mathbf{7 3 6 . 3 2 5}$ & $\mathbf{7 9 1 . 3 2 5}$ \\
\hline
\end{tabular}

Dari Tabel 9 dapat diketahui bahwa besarnya rata-rata biaya total untuk setiap kali proses produksi kripik pisang adalah Rp 906.825, sedangkan pada proses produksi sale pisang biaya total Rp. 736.325 dan Rp 791.325 biaya untuk proses produksi kripik ubi. Dari total biaya yang dikeluarkan terlihat bahwa Aneka Kripik Putri Tunggal memiliki kapasitas usaha kripik pisang yang lebih besar dibandingkan dengan sale pisang dan kripik ubi.

\section{Penerimaan dan Keuntungan}

Penerimaan merupakan hasil dari perkalian antara jumlah produksi kripik yang dihasilkan dengan harga jual dengan satuan rupiah dalam satu kali proses produksi. Keuntungan merupakan selisih antara penerimaan total (TR) dengan biaya total (TC). Besarnya penerimaan dan keuntungan untuk tiap kali proses produksi pada Perusahaan Putri Tunggal dapat dilihat pada Tabel 10

Tabel 10. Penerimaan dan Keuntungan per Proses Produksi Aneka Kripik Putri Tunggal

\begin{tabular}{|l|c|c|c|}
\hline \multirow{2}{*}{\multicolumn{1}{|c|}{ Uraian }} & \multicolumn{3}{|c|}{ Nilai (Rp) } \\
\cline { 2 - 4 } & Kripik Pisang & Sale Pisang & Kripik Ubi \\
\hline Penerimaan (bks/harga) & 1.200 .000 & 600.000 & 1.120 .000 \\
\hline Biaya Pengolahan & & & \\
\hline Biaya Tetap & 302.325 & 302.325 & 302.325 \\
\hline Biaya Varaibel & 604.500 & 434.000 & 489.000 \\
\hline Total Biaya & 906.825 & 736.325 & 791.325 \\
\hline Keuntungan & $\mathbf{2 9 3 . 1 7 5}$ & $\mathbf{( 1 3 6 . 3 2 5 )}$ & $\mathbf{3 2 8 . 6 7 5}$ \\
\hline
\end{tabular}

Berdasarkan Tabel 10, dengan output sebesar 300 bungkus rata-rata normal produksi penerimaan kripik pisang dapat diketahui untuk satu kali proses produksi adalah Rp 293.175, serta keuntungan yang diperoleh untuk satu kali proses produksi kripik ubi adalah $\mathrm{Rp}$ 328.675, sedangkan untuk sale pisang produksi mengalami kerugian untuk tiap satu kali proses produksi adalah sebesar (136.325) atau tidak mngalami keuntungan. Total keuntungan atau pendapatan yang diterima dari aneka usaha 
kripik Putri Tunggal dalam satu kali proses adalah Rp. 485.525

\section{Revenue Cost Ratio (R/C) dan Analisis Titik Impas (BEP)}

\section{Revenue Cost Ratio (R/C)}

Perhitungan nilai $\mathrm{RC}$ ratio pada aneka kripik Putri Tunggal dapat dilihat pada Tabel 11.

Tabel 11. Nilai R/C Ratio pada Aneka Kripik Putri Tunggal

\begin{tabular}{|l|r|r|r|}
\hline \multirow{2}{*}{\multicolumn{1}{|c|}{ Uraian }} & \multicolumn{3}{|c|}{ Nilai (Rp) } \\
\cline { 2 - 4 } & Kripik Pisang & Sale Pisang & Kripik Ubi \\
\hline Penerimaan (TR) & 1.200 .000 & 600.000 & 1.120 .000 \\
\hline Biaya Total (TC) & 906.825 & 736.325 & 791.325 \\
\hline R/C rasio & 1,32 & 0,81 & 1,42 \\
\hline R/C Total & \multicolumn{3}{|c|}{1.12} \\
\hline
\end{tabular}

Berdasarkan Tabel 11 diketahui bahwa nilai perbandingan antara penerimaan dan biaya produksi total adalah sebesar 1,32. Hal ini berarti setiap Rp 1.000 biaya yang dikeluarkan akan menghasilkan penerimaan sebesar Rp 1.320 keripik pisang. Sedangkan nilai $\mathrm{R} / \mathrm{C}$ ratio sale pisang adalah sebesar 0,81 yang berarti setiap $\mathrm{Rp} 1.000,00$ biaya atau modal yang dikeluarkan akan menghasilkan penerimaan sebesar $\mathrm{Rp} 810$, dan nilai $\mathrm{R} / \mathrm{C}$ kripik ubi 1,42, hal ini berarti Rp. 1.000 yang dikeluarkan akan menghasilkan penerimaan Rp. 1.420. Nilai $\mathrm{R} / \mathrm{C}$ ratio yang dihasilkan usaha agroindustri tersebut lebih dari satu berarti usaha pengolahan pisang menjadi kripik pisang dan keripik ubi menguntungkan perusahaan sedangkan sale pisang kurang menguntungkan. Dan untuk R/C total adalah 1,12

\section{Analisis Titik Impas (BEP)}

Pada Perusahaan Putri Tunggal akan berada pada kondisi Break Even Point dalam unit pada saat perusahaan hanya memproduksi 302 bungkus kripik pisang, dengan harga jual Rp. 4.030,-. Sedangkan sale pisang akan berada pada kondisi titik impas dalam unit pada saat perusahaan hanya memproduksi 260 bungkus sale pisang, dengan harga jual Rp. 6.924,- dan untuk produksi kripik ubi akan mengalami kondisi titik impas jika perusahaan memproduksi 273 bungkus dengan harga jual RRp. 3.905,-. Dan untuk BEP total produksi aneka kripik Putri Tunggal akan berada pada titik impas jika produksi 730 bungkus dengan harga jual Rp. 2.925

Tabel 12. Nilai BEP pada Perusahaan Aneka Kripik Putri Tunggal

\begin{tabular}{|l|r|r|r|}
\hline \multirow{2}{*}{\multicolumn{1}{|c|}{ Uraian }} & \multicolumn{3}{|c|}{ Nilai (Rp) } \\
\cline { 2 - 5 } & Kripik Pisang & Sale Pisang & Kripik Ubi \\
\hline Biaya Tetap (Rp) & 302.325 & 302.325 & 302.325 \\
\hline Biaya Variabel (Rp) & 906.825 & 736.325 & 791.325 \\
\hline Volume produksi & 300 & 150 & 280 \\
\hline Harga Jual (Rp/bks) & 4.000 & 4.000 & 4.000 \\
\hline Penerimaan (Rp) & 1.200 .000 & 600.000 & 1.120 .000 \\
\hline BEP Volume Produksi (Bks) & 302 & 260 & 273 \\
\hline BEP Penerimaa (Rp) & 4.030 & 6.924 & 3.905 \\
\hline BEP Volume Total (Bks) & \multicolumn{3}{|c|}{730} \\
\hline BEP Penerimaan (Rp) & \multicolumn{4}{|c|}{2.925} \\
\hline
\end{tabular}




\section{JSA}

Berdasarkan hasil penelitian dan analisis data yang telah dilakukan pada Perusahaan Aneka Kripik Putri Tunggal yang terletak di Kelurahan Dusun Bangko Kecamatan Bangko Kabupaten Merangin dapat diambil kesimpulan bahwa :

1. Dengan output sebesar 300 bungkus rata-rata normal produksi penerimaan kripik pisang dapat diketahui untuk satu kali proses produksi adalah Rp 293.175, serta keuntungan yang diperoleh untuk satu kali proses produksi kripik ubi adalah Rp 328.675, sedangkan untuk sale pisang produksi mengalami kerugian untuk tiap satu kali proses produksi adalah sebesar (136.325) atau tidak mngalami keuntungan, dengan total keuntungan Rp. 485.525

2. Kegiatan usaha pengolahan aneka kripik Putri Tunggal mempunyai nilai perbandingan antara penerimaan dan biaya produksi total adalah sebesar 1,32. Hal ini berarti setiap Rp 1.000 biaya yang dikeluarkan akan menghasilkan penerimaan sebesar Rp 1.320 keripik pisang. Sedangkan nilai $\mathrm{R} / \mathrm{C}$ ratio sale pisang adalah sebesar 0,81 yang berarti setiap $\mathrm{Rp} 1.000,00$ biaya atau modal yang dikeluarkan akan menghasilkan penerimaan sebesar Rp 810, dan nilai R/C kripik ubi 1,42, hal ini berarti Rp. 1.000 yang dikeluarkan akan menghasilkan penerimaan Rp. 1.420 dan untuk R/C total dari usaha industri aneka kripik Putri Tunggal sebesar Rp. 1,12. Nilai $\mathrm{R} / \mathrm{C}$ ratio yang dihasilkan usaha agroindustri tersebut lebih dari satu berarti usaha pengolahan pisang menjadi kripik pisang dan keripik ubi menguntungkan perusahaan sedangkan sale pisang kurang menguntungkan.
3. Pada aneka Putri Tunggal akan berada pada kondisi Break Even Point dalam unit pada saat perusahaan hanya memproduksi 302 bungkus kripik pisangdengan harga jual Rp. 4.030,-. Sedangkan sale pisang akan berada pada kondisi titik impas dalam unit pada saat perusahaan hanya memproduksi 260 bungkus sale pisang, dengan harga jual Rp. 6.924,dan untuk produksi kripik ubi akan mengalami kondisi titik impas jika perusahaan memproduksi 273 bungkus dengan harga jual Rp. 3.905,. Sedangkan untuk Break Event Point total untuk produksi dari aneka kripik Putri Tunggal adalah bila memproduksi 730 bungkus dengan harga jual Rp. 2.925

\section{Daftar Pustaka}

Daniel, M. 2002. Pengantar Ekonomi Pertanian. Bumi Aksara, Jakarta.

Hayami, Y. et al. 1987. Agricultural marketing and processing in upland Java. A perspective from a Sunda village. Bogor: CGPRT Centre.

Kotler, Philip. 2003. Manajemen Pemasaran, Jilid 1 Indeks Kelompok. Gramedia. Jakarta.

Mulyadi. 2001. Uphas Gia Salis "Blog Archive" Analisis Finansial Usahatani (Teori dan Konsep).htm. diposting tanggal 20 Maret 2011.

Noor, Hendry Faizal. 2007. Ekonomi Manajerial. Jakarta: RajaGrafindo Persada.

Redaksi Trubus. 1999. Mengatur Tanaman Berbuah. Penebar Swadaya: Surabaya.

Rismunandar. 1971. Bertanam Pisang. Sinar Baru. Bandung.

Rukmana, Rahmat. 1999. Usahatani Pisang. Kanisius. Yogyakarta.

Santoso, Budi. 1995. Saus Pisang. Kanisius. Yogyakarta

Soekartawi. 1984. Ilmu Usahatani dan Penelitian untuk Pengembangan Petani Kecil. Jakarta : UI Press. 
Sunarjo, Hendro. 1990. Ilmu Produksi Tanaman Buah-buahan. Sinar Baru. Bandung

Sumarjo, dkk. 2004. Teori dan Praktik Kemitraan Agribisnis. Swadaya. Jakarta.

Suryana, A. 2005. Arah, Strategi dan Program Pembangunan Pertanian 2005- 2009. Badan Penelitian dan Pengembangan Pertanian. Departemen Pertanian. Jakarta.

Tim Lentera. 2002. Kiat Mengatasi Permasalahan Praktis. Jakarta : Agro Media Pustaka. Tim 2005. Road Map Pisang: Pasca Panen, Pengolahan, dan

Pemasaran Hasil Pisang. Direktorat

Pengolahan dan Pemasaran Hasil

Hortikultura. 